\title{
Basiliximab as therapy for acute rejection after liver transplantation for hepatitis $\mathrm{C}$ virus cirrhosis
}

\author{
Junichi Togashi ${ }^{1}$, Yasuhiko Sugawara ${ }^{1, *}$, Sumihito Tamura ${ }^{1}$, Junichi Kaneko ${ }^{1}$, Noriyo Yamashiki ${ }^{2}$, \\ Taku Aoki ${ }^{1}$, Kiyoshi Hasegawa ${ }^{1}$, Norihiro Kokudo ${ }^{1}$ \\ ${ }^{1}$ Artificial Organ and Transplantation Surgery Division, Department of Surgery, Graduate School of Medicine, The University of \\ Tokyo, Tokyo, Japan; \\ ${ }^{2}$ Organ Transplantation Service, The University of Tokyo Hospital, Tokyo, Japan.
}

\begin{abstract}
Summary Steroid bolus therapy for acute rejection after liver transplantation for hepatitis C virus (HCV) cirrhosis often results in graft loss due to adverse effects. The efficacy and safety of basiliximab for the treatment of acute cellular rejection (ACR) in adult liver transplantation has not been adequately evaluated. Three patients received basiliximab as rescue therapy for acute rejection. The outcome and biochemical parameters were recorded before and after treatment with basiliximab. These results were compared to 11 patients who received steroid therapy for ACR. The median time from transplantation to the development of ACR was 19 days (range, 9-49 days). The degree of ACR was mild or moderate. Resolution of rejection was obtained in all patients and the median time from the onset to resolution of ACR was 16 days (range, 6-41 days). A steroid resistant reaction occurred in 2 of 11 patients and OKT3 was used, and the rejection eventually resolved in all patients. Five patients died within 2 to 22 months after transplantation and four of them died from graft failure. In the basiliximab group, there were no significant immediate adverse effects. One patient died from pneumonia 8 months after transplantation. In conclusion: Basiliximab can be safely used as rescue therapy for ACR without significant adverse effects in patients who underwent liver transplantation for HCV cirrhosis.
\end{abstract}

Keywords: Hepatitis C, donor, living donor liver transplantation

\section{Introduction}

Liver transplantation is an effective treatment for endstage liver disease due to hepatitis $\mathrm{C}$ virus (HCV). Despite major advances in immunosuppression, acute cellular rejection (ACR) remains a significant postoperative issue. This can be a major risk factor for the development of chronic allograft rejection and graft loss. Despite the use of calcineurin inhibitors, ACR occurs in $36 \%$ to $57 \%$ of transplant recipients (1). Typical management involves optimization of baseline immunosuppression and methylprednisolone

\footnotetext{
*Address correspondence to:

Yasuhiko Sugawara, Artificial Organ and Transplantation Surgery Division, Department of Surgery, Graduate School of Medicine, The University of Tokyo, 7-3-1 Hongo, Bunkyo-ku, Tokyo, 113-8655, Japan. e-mail: yasusuga-tky@umin.ac.jp
}

boluses. In addition, $28 \%$ to $35 \%$ (2) of patients do not respond to high-dose steroid therapy and require further intervention, including antithymocyte globulin or OKT3. Repeated high-dose steroids and OKT3, however, reduce graft survival as a consequence of severe HCV recurrence (3).

Basiliximab is a chimeric (human/mouse) monoclonal antibody that selectively binds to the $\alpha$ subunit (CD25) of the interleukin-2 (IL-2) receptor (4), preventing normal T-cell proliferation and thereby the progression of ACR (5). IL-2 promotes the proliferation of activated $\mathrm{T}$ cells by engaging the IL- 2 receptor, and this has a crucial role in the mediation of ACR. The efficacy of basiliximab has been evaluated and has been shown to rescue the graft from ACR (6). In the present study, we examined the efficacy and safety of basiliximab as a therapeutic agent for rescue of ACR in liver recipients for HCV-related cirrhosis, in comparison with conventional high-dose steroid therapy. 


\section{Patients and Methods}

We performed 213 adult liver transplantations from 2004 to September 2010. Of these, 89 were transplanted due to HCV cirrhosis (4 patients coinfected with HIV were excluded). Of the 89 patients, $16(18 \%)$ were complicated with ACR within 60 days after transplantation at the University of Tokyo Hospital. The ACR rate in the patients other than HCV during the same period was $29 \%(n=294)$ which was higher than that of HCV patients without significant difference. After transplantation, all of the patients received the same immunosuppressive treatment with tacrolimus and methylprednisolone, as described previously (7). Briefly, target tacrolimus trough levels were 15 to $20 \mathrm{ng} / \mathrm{mL}$ during the first 2 weeks and 10 to $15 \mathrm{ng} / \mathrm{mL}$ thereafter. Intravenous methylprednisolone was started during the operation $(20 \mathrm{mg} / \mathrm{kg} /$ day $)$, and gradually tapered thereafter ( 7 days after transplantation, $0.75 \mathrm{mg} / \mathrm{kg}$; two weeks, $0.35 \mathrm{mg} / \mathrm{kg}$; one month, $0.3 \mathrm{mg} / \mathrm{kg}$; two months, $0.25 \mathrm{mg} / \mathrm{kg}$; three months, $0.2 \mathrm{mg} / \mathrm{kg}$; 4 months, $0.2 \mathrm{mg} / \mathrm{kg}$ ). The subjects comprised 12 men and 4 women who underwent liver transplantation with subsequent development of ACR. ACR was defined as a biopsy-proven episode and graded according to the Banff schema (8). The indication for liver biopsy was a significant increase in total bilirubin, aspartate, and alanine aminotransferase levels.

Until the end of 2007, the patients were treated with bolus intravenous methylprednisolone, regardless of ACR severity, at a starting dose of $20 \mathrm{mg} / \mathrm{kg} / \mathrm{day}$, as previously described (9). The dose was reduced by half each day and the therapy was continued for 5 days. When acute rejection was refractory to highdose methylprednisolone therapy, a second bolus was then given with mycofenolate mofitile (CellCept, Roche Pharmaceuticals, Basel, Switzerland; 3 g/day). If the rejection was not cured by two rounds of steroid therapy the episode was diagnosed as steroid-resistant

\section{Steroid Group}

FK+steroid recycle
$\downarrow$ Fail
FK+steroid recycle+MMF 3g/d
$\downarrow$ Fail
OKT3

\section{Basiliximab Group}

\section{FK+steroid maintenance+basiliximab}

Figure 1. Regimens in the steroid and basiliximab groups. Abbreviations: FK, tacrolimus; MMF, mycophenolate mofetil. rejection and OKT3 was administered (Figure 1). After 2008, the regimen was changed. Basiliximab (two 20-mg doses with a 2-day inter-dose interval; Simulect, Novartis Pharmaceuticals, Basel, Switzerland) was added to the immunosuppressive treatment with tacrolimus and methylprednisolone. No bolus intravenous methylprednisolone was administered. The primary outcome measures were treatment success with resolution of $\mathrm{ACR}$, as indicated by normalization of alanine aminotransferase or resolution of liver biopsy changes, or treatment failure due to ongoing rejection. No infectious prophylaxis was done. Immediate treatment of adverse effects and infectious complications within 1 month of treatment were recorded.

\section{Results and Discussion}

The median time from transplantation to the development of ACR was 19 days (range, 9-49 days). The degree of ACR was mild or moderate. Median follow-up from transplantation was 25 months (range, 2-81 months).

Treatment outcomes are summarized in Table 1. Of the 11 patients in the steroid group, 2 had a steroidresistant reaction and OKT3 was used. The overall rejection grade in the two patients was moderate. In a semi quantitative assessment, venous endothelial inflammation was scored as 2 (moderate). Rejection eventually resolved in all patients, which was confirmed by the subsequent biopsy in 7 . Five patients died within 2 to 22 months after transplantation and four of them died from graft failure. In all three patients in the basiliximab group, rejection resolved without significant immediate adverse effects. In one patient the resolution was histologically confirmed (Banff rejection activity index changed from 4 to 2 after the therapy). One patient died of pneumonia 8 months after transplantation.

Aspartate aminotransferase levels normalized in all patients. The median time from the onset to resolution of ACR was 16 days (range, 6-41 days).

The present report confirms that basiliximab can be effective in reversing ACR in HCV patients. All patients with histologic evidence of ACR before treatment with basiliximab had resolution of ACR. Three patients with ACR were managed effectively with basiliximab without the addition of other immunosuppressive agents. Furthermore, none of these patients had recurrent episodes of ACR. In contrast, of the 11 patients complicated with ACR that received steroid pulse therapy, 4 died of graft failure, probably due to HCV recurrence, although ACR was successfully resolved in all cases.

The safety of basiliximab was previously reported, with no evidence of significant acute toxicity $(2,10)$ or increased risk of infection (11). There have been 
Table 1. Patients and treatment outcomes

\begin{tabular}{|c|c|c|c|c|c|c|c|c|c|c|c|}
\hline \multirow{2}{*}{ Age, sex } & \multirow{2}{*}{$\begin{array}{l}\text { ACR } \\
\text { onset (d) }\end{array}$} & \multicolumn{2}{|c|}{ On the day ACR diagnosis } & \multirow{2}{*}{$\begin{array}{l}\text { Number of } \\
\text { steroid boluses }\end{array}$} & \multirow{2}{*}{ MMF } & \multirow{2}{*}{$\mathrm{OKT}$} & \multirow{2}{*}{$\begin{array}{l}\text { Interval for } \mathrm{ACR} \\
\text { resolution }(\mathrm{d})\end{array}$} & \multicolumn{2}{|c|}{ After the therapy } & \multirow{2}{*}{ Outcome } & \multirow{2}{*}{$\begin{array}{c}\text { Cause of } \\
\text { death }\end{array}$} \\
\hline & & $\begin{array}{l}\text { Banff } \\
\text { score }\end{array}$ & $\begin{array}{c}\text { Blood test } \\
\text { (ALT/ALP/TB) }\end{array}$ & & & & & $\begin{array}{l}\text { Banff } \\
\text { score }\end{array}$ & $\begin{array}{c}\text { Blood test } \\
\text { (ALT/ALP/TB) }\end{array}$ & & \\
\hline \multicolumn{12}{|c|}{ Steroid group } \\
\hline $44, \mathrm{M}$ & 42 & 3 & $314 / 546 / 0.7$ & 1 & No & No & 23 & - & $36 / 471 / 1.2$ & $81 \mathrm{~A}$ & - \\
\hline $57, \mathrm{M}$ & 11 & 4 & $86 / 521 / 1.3$ & 3 & Yes & No & 39 & 2 & $28 / 338 / 0.8$ & $81 \mathrm{~A}$ & _- \\
\hline $57, \mathrm{M}$ & 39 & 3 & $58 / 752 / 0.7$ & 1 & No & No & 26 & - & $30 / 461 / 0.5$ & $80 \mathrm{~A}$ & - \\
\hline $48, \mathrm{~F}$ & 34 & 5 & $315 / 180 / 1.1$ & 3 & Yes & Yes & 8 & 2 & $30 / 121 / 2.6$ & $3 \mathrm{D}$ & Graft failure \\
\hline $63, \mathrm{M}$ & 18 & 4 & $89 / 318 / 0.8$ & 1 & No & No & 10 & - & $33 / 218 / 0.6$ & $73 \mathrm{~A}$ & - \\
\hline $45, \mathrm{M}$ & 30 & 5 & $192 / 143 / 2.9$ & 2 & Yes & Yes & 12 & 1 & $44 / 180 / 3.6$ & $22 \mathrm{D}$ & Graft failure \\
\hline $49, \mathrm{M}$ & 16 & 3 & $185 / 269 / 1.9$ & 2 & Yes & No & 40 & 1 & $30 / 258 / 3.1$ & $3 \mathrm{D}$ & Graft failure \\
\hline $47, \mathrm{M}$ & 9 & 3 & $44 / 134 / 1.4$ & 1 & No & No & 12 & - & $14 / 118 / 0.7$ & $58 \mathrm{~A}$ & - \\
\hline $47, \mathrm{M}$ & 9 & 3 & $45 / 229 / 14.5$ & 2 & Yes & No & 41 & 1 & $34 / 470 / 9.2$ & $2 \mathrm{D}$ & Graft failure \\
\hline $49, \mathrm{M}$ & 12 & 4 & $127 / 288 / 0.9$ & 1 & No & No & 17 & 1 & $35 / 225 / 0.5$ & $50 \mathrm{~A}$ & - \\
\hline $58, \mathrm{~F}$ & 19 & 3 & $45 / 469 / 4.5$ & 1 & No & No & 38 & 1 & $35 / 431 / 3.1$ & $9 \mathrm{D}$ & TMA \\
\hline \multicolumn{12}{|c|}{ Basiliximab group } \\
\hline $55, \mathrm{M}$ & 44 & 3 & $125 / 888 / 0.5$ & 0 & No & No & 7 & - & $14 / 432 / 0.5$ & $27 \mathrm{~A}$ & - \\
\hline $61, \mathrm{~F}$ & 49 & 4 & $112 / 1077 / 2.1$ & 0 & Yes & No & 15 & 2 & $48 / 653 / 1.6$ & $8 \mathrm{D}$ & Pneumonia \\
\hline $60, \mathrm{~F}$ & 19 & 3 & $100 / 448 / 3.5$ & 0 & No & No & 6 & - & $36 / 265 / 2.2$ & $3 \mathrm{~A}$ & - \\
\hline
\end{tabular}

Abbreviations: ACR, acute cellular rejection; A, alive; D, dead; TMA, thrombomicroangiopathy; MMF, mycophenolate mofetil; ALT/ALP/TB, alanine aminotransferase (IU/L)/alkaline phosphatase (IU/L)/total bilirubin (md/dL).

several reports of cytomegalovirus viremia after induction with anti-IL-2 receptor antibodies, but to date there is no evidence of a significant increased risk of cytomegalovirus infection (12). In this series, one patient died of pneumonia 8 months after liver transplantation, which may not be directly attributable to basiliximab therapy.

$\mathrm{HCV}$ recurrence developed in most $\mathrm{HCV}$-positive recipients. The intensity of immunosuppression correlates with recurrent $\mathrm{HCV}$ hepatitis after transplantation (13). Importantly, Kato et al. (14) reported that tacrolimus along with daclizumab and a steroid-free regimen resulted in fewer HCV infection recurrences after transplantation. The use of basiliximab therefore seems to be advantageous over steroid therapy in $\mathrm{HCV}$-positive patients.

Our results are comparable to those of other case series in which basiliximab was used as rescue therapy. Orr et al. (15) used basiliximab in 16 patients with steroid-resistant ACR, and resolution was achieved in $12(75 \%)$ cases. Similarly, in another study (16), $5(71.4 \%)$ of 7 liver transplant recipients with steroid-resistant ACR were successfully treated with basiliximab. Another series (6) showed resolution of ACR in adult renal and liver recipients, $72 \%$ of whom were successfully treated with basiliximab. The findings of that study (6) suggest that the efficacy of anti-IL-2 receptor antibody in ACR is similar to that of high-dose steroids, although there are no prospective randomized trials that have tested this hypothesis.

Anti-IL-2 receptor antibodies are now widely used in liver transplantation as induction agents targeted at reducing the incidence of $\operatorname{ACR}(2,17,18)$ or as a calcineurin-inhibitor (19) or steroid-sparing strategy $(20,21)$ to protect renal function in the immediate postoperative period. Comparison of induction therapy (12) between antithymocyte globulin + cyclosporine + steroid + azathioprine and anti-IL-2 receptor antibody
+ tacrolimus + steroid + azathioprine demonstrated a reduced ACR incidence in the anti-IL-2 receptor antibody group (43\% versus $29 \%$; $p<0.01$ ). Patients treated with anti-IL-2 receptor antibodies also had fewer infective complications. The results of a metaanalysis of treatment with anti-IL-2 receptor antibodies in renal transplantation (22) confirmed that the risk for ACR was reduced by $49 \%$ at 6 months. Importantly, however, their use did not significantly reduce graft loss or mortality at 1 year. Prospective randomized studies comparing calcineurin inhibitors + steroid + basiliximab and calcineurin inhibitors + steroid showed a lower (23) or similar $(24,25)$ ACR rate and no difference in graft survival.

A limitation of this study is that it was a retrospective and nonrandomized case series. The small number of patients enrolled in the study was insufficient to yield statistically meaningful results. These preliminary data, however, indicate that the use of anti-IL-2 receptor antibodies is safe for the treatment of ACR in HCV-positive patients. Prospective studies are now needed to evaluate the use of anti-IL-2 receptor antibodies as a first-line therapy for ACR for HCVpositive patients.

\section{Acknowledgements}

This project was supported by a grant-in-aid for Scientific Research from the Ministry of Education, Culture, Sports, and Science of Japan.

\section{References}

1. Shapiro R, Young JB, Milford EL, Trotter JF, Bustami RT, Leichtman AB. Immunosuppression: Evolution in practice and trends, 1993-2003. Am J Transplant. 2005; 5:874-886.

2. Nashan B, Schlitt HJ, Schwinzer R, Ringe B, Kuse E, 
Tusch G, Wonigeit K, Pichlmayr R. Immunoprophylaxis with a monoclonal anti-IL-2 receptor antibody in liver transplant patients. Transplantation. 1996; 61:546-554.

3. Neumann UP, Berg T, Bahra M, Puhl G, Guckelberger O, Langrehr JM, Neuhaus P. Long-term outcome of liver transplants for chronic hepatitis C: A 10-year follow-up. Transplantation. 2004; 77:226-231.

4. Ramirez CB, Marino IR. The role of basiliximab induction therapy in organ transplantation. Expert Opin Biol Ther. 2007; 7:137-148.

5. Nikaido T, Shimizu A, Ishida N, Sabe H, Teshigawara K, Maeda M, Uchiyama T, Yodoi J, Honjo T. Molecular cloning of cDNA encoding human interleukin-2 receptor. Nature. 1984; 311:631-635.

6. Chariat MN, Erren M, Chariat M, Deng M, Wolters HH, Dietl KH. Basiliximab in the therapy of acute rejection after organ transplantation. Transplant Proc. 2001; 33:2380.

7. Sugawara Y, Mizuta K, Kawarasaki H, Takayama $\mathrm{T}$, Imamura H, Makuuchi M. Risk factors for acute rejection in pediatric living related liver transplantation: The impact of HLA matching. Liver Transpl. 2001; 7:769-773.

8. Terminology for hepatic allograft rejection. International Working Party. Hepatology. 1995; 22:648-654.

9. Sugawara Y, Tamura S, Kaneko J, Togashi J, Makuuchi M, Kokudo N. Positive lymphocytotoxic crossmatch does not adversely affect survival in living donor liver transplantation. Dig Surg. 2009; 26:482-486.

10. Friend PJ, Waldmann H, Cobbold S, et al. The antiIL-2 receptor monoclonal antibody YTH-906 in liver transplantation. Transplant Proc. 1991; 23:1390-1392.

11. Raakow R, Steffen R, Knoop M, Blumhardt G, Lemmens P, Wiens M, Keck H, Neuhaus P. Quadruple immunosuppression including a new IL-2-receptor antibody and the incidence of infections after liver transplantation. Transpl Int. 1992; 5:S168-S169.

12. Langrehr JM, Schneller A, Guckelberger O, Lohmann R, Neumann U, Jonas S, Klupp J, Settmacher U, Knoop M, Bechstein WO, Neuhaus PJ. Comparison of quadruple induction including ATG or IL-2R antibody with FK506based therapy after liver transplantation. Transplant Proc. 1998; 30:1439-1440.

13. Gayowski T, Singh N, Marino IR, Vargas H, Wagener M, Wannstedt C, Morelli F, Laskus T, Fung JJ, Rakela J, Starzl TE. Hepatitis $C$ virus genotypes in liver transplant recipients: Impact on posttransplant recurrence, infections, response to interferon-alpha therapy and outcome. Transplantation. 1997; 64:422-426.

14. Kato T, Gaynor JJ, Yoshida H, Montalvano M, Takahashi H, Pyrsopoulos N, Nishida S, Moon J, Selvaggi G, Levi D, Ruiz P, Schiff E, Tzakis A. Randomized trial of steroid-free induction versus corticosteroid maintenance among orthotopic liver transplant recipients with hepatitis $C$ virus: Impact on hepatic fibrosis progression at one year. Transplantation. 2007; 84:829-835.

15. Orr DW, Portmann BC, Knisely AS, Stoll S, Rela M, Muiesan P, Bowles MJ, Heaton ND, O'Grady JG, Heneghan MA. Anti-interleukin 2 receptor antibodies and mycophenolate mofetil for treatment of steroid- resistant rejection in adult liver transplantation. Transplant Proc. 2005; 37:4373-4379.

16. Aw MM, Taylor RM, Verma A, Parke A, Baker AJ, Hadzic D, Muiesan P, Rela M, Heaton ND, MieliVergani G, Dhawan A. Basiliximab (Simulect) for the treatment of steroid-resistant rejection in pediatric liver transpland recipients: A preliminary experience. Transplantation. 2003; 75:796-799.

17. Ramirez CB, Doria C, di Francesco F, Iaria M, Kang Y, Marino IR. Anti-IL2 induction in liver transplantation with $93 \%$ rejection-free patient and graft survival at 18 months. J Surg Res. 2007; 138:198-204.

18. Gruttadauria S, Mandala L, Biondo D, Spampinato M, Lamonaca V, Volpes R, Vizzini G, Marsh J, Marcos A, Gridelli B. Role of basiliximab in the prevention of acute cellular rejection in adult to adult living-related liver transplantation: A single center experience. Biologics. 2007; 1:69-73.

19. Lin CC, Chuang FR, Lee CH, Wang CC, Chen YS, Liu YW, Jawan B, Chen CL. The renal-sparing efficacy of basiliximab in adult living donor liver transplantation. Liver Transpl. 2005; 11:1258-1264.

20. Lladó L, Xiol X, Figueras J, Ramos E, Memba R, Serrano T, Torras J, Garcia-Gil A, Gonzalez-Pinto I, Castellote J, Baliellas C, Fabregat J, Rafecas A; Thosin Study Group. Immunosuppression without steroids in liver transplantation is safe and reduces infection and metabolic complications: Results from a prospective multicenter randomized study. J Hepatol. 2006; 44:710-716.

21. Gras JM, Gerkens S, Beguin C, Janssen M, Smets F, Otte JB, Sokal E, Reding R. Steroid-free, tacrolimusbasiliximab immunosuppression in pediatric liver transplantation: Clinical and pharmacoeconomic study in 50 children. Liver Transpl. 2008; 14:469-477.

22. Adu D, Cockwell P, Ives NJ, Shaw J, Wheatley K. Interleukin-2 receptor monoclonal antibodies in renal transplantation: Meta-analysis of randomised trials. BMJ. 2003; 326:789.

23. Neuhaus P, Clavien PA, Kittur D, Salizzoni M, Rimola A, Abeywickrama K, Ortmann E, Chodoff L, Hall M, Korn A, Nashan B. Improved treatment response with basiliximab immunoprophylaxis after liver transplantation: Results from a double-blind randomized placebo-controlled trial. Liver Transpl. 2002; 8:132-142.

24. Lupo L, Panzera P, Tandoi F, Carbotta G, Giannelli G, Santantonio T, Rendina M, Gentile A, Memeo V. Basiliximab versus steroids in double therapy immunosuppression in liver transplantation: A prospective randomized clinical trial. Transplantation. 2008; 86:925-931.

25. Schmeding M, Sauer IM, Kiessling A, Pratschke J, Neuhaus R, Neuhaus P, Neumann UP. Influence of basiliximab induction therapy on long term outcome after liver transplantation, a prospectively randomised trial. Ann Transplant. 2007; 12:15-21.

(Received March 24, 2011; Revised April 15, 2011; Accepted April 16, 2011) 